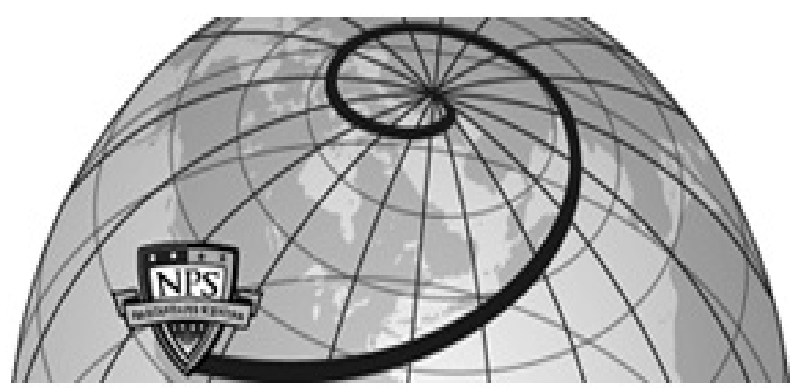

Calhoun: The NPS Institutional Archive DSpace Repository

Scheduling Peacetime Rotation of Pakistan Army Units

Dell, Robert F.; Rosenthal, Richard E.; Baig, Shafqat Monterey, California. Naval Postgraduate School

https://hdl.handle.net/10945/30153

This publication is a work of the U.S. Government as defined in Title 17, United States Code, Section 101. Copyright protection is not available for this work in the United States.

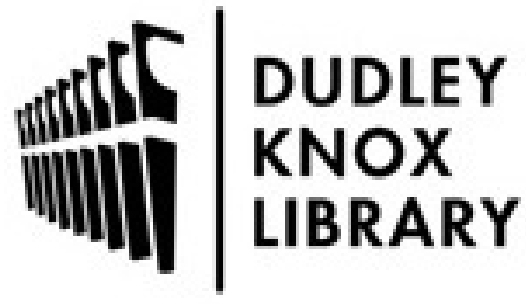

http://www.nps.edu/library
Calhoun is the Naval Postgraduate School's public access digital repository for research materials and institutional publications created by the NPS community. Calhoun is named for Professor of Mathematics Guy K. Calhoun, NPS's first appointed -- and published -- scholarly author.

Dudley Knox Library / Naval Postgraduate School 411 Dyer Road / 1 University Circle Monterey, California USA 93943 
NPS-OR-93-023

\section{NAVAL POSTGRADUATE SCHOOL Monterey, California}

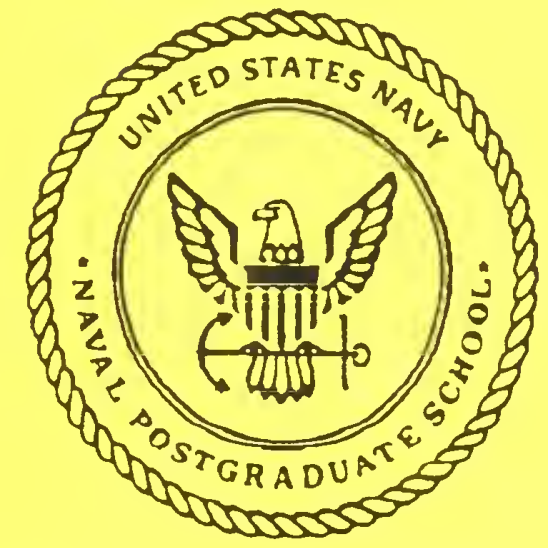

\section{SCHEDULING PEACETIME ROTATION OF PAKISTAN ARMY UNITS}

\section{Robert F. Dell}

Richard E. Rosenthal

Shafquat Baig

November 1993

Approved for public release; distribution is unlimited.

FedDocs

D 208.14/2

NPS-OR-93-023

Prepared for:

Javal Postgraduate School

Monterey, CA 93943 


\section{NAVAL POSTGRADUATE SCHOOL MONTEREY, CA 93943-5000}

Rear Admiral T. A. Mercer

Harrison Shull

Superintendent

Provost

This report was prepared for and funded by the Naval Postgraduate School.

Reproduction of all or part of this report is authorized.

This report was prepared by: 


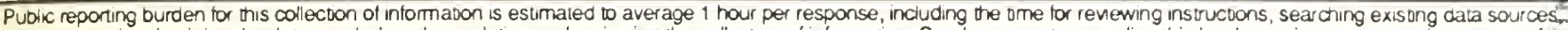

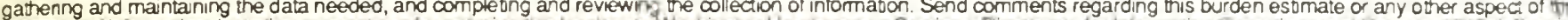

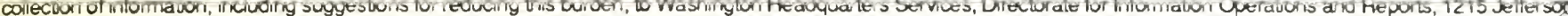

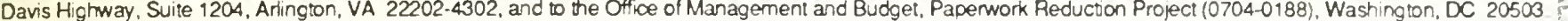
1. AGENCY USE ONLY (Leave blank)
2. REPORT DATE
3. REPORT TYPE AND DATES COVERED

November 1993

Technical

4. TITLE AND SUBTITLE

Scheduling Peacetime Rotation of Pakistan Army Units

5. FUNDING NUMBERS

RNX2DP

6. AUTHOR(S)

Robert F. Dell, Richard E. Rosenthal, and Shafqat Baig

7. PERFORMING ORGANIZATION NAME(S) AND ADDRESS(ES)

8. PERFORMING ORGANIZATION REPORT NUMBER

Naval Postgraduate School

Monterey, CA 93943

NPS-OR-93-023

9. SPONSORING / MONITORING AGENCY NAME(S) AND ADDRESS(ES)

10. SPONSORING / MONITORING AGENCY REPORT NUMBER

Naval Postgraduate School

Monterey, CA 93943

11. SUPPLEMENTARY NOTES

12a. DISTRIBUTION / AVAILABILITY STATEMENT

12b. DISTRIBUTION CODE

Approved for public release; distribution is unlimited.

\section{ABSTRACT (Maximum 200 words)}

Since Pakistan has varying climates and terrains, the Pakistan Army rotates its units between peacetime locations so that no unit endures inequitable hardship or enjoys unfair advantage. Army policy specifies strict constraints on unit rotations, such as the length of a unit's stay in any location, the number of units moving at any time, and the allowable replacements for any moving unit. Scheduling rotations manually in accordance with these rules, as is currently practiced, is extremely difficult and time-consuming. This paper presents an integer programming model that finds feasible, minimum-cost schedules for the Pakistan Army's desired planning horizons. The model also ensures that the units are positioned at the end of the planning horizon so that feasible schedules exist for future planners. The model is implemented with commercially available optimization software. Schedules are obtained for realistic test problems in less than an hour on a personal computer.

14. SUBJECT TERMS

Integer programming application, Scheduling, Timetabling

17. SECURITY CLASSIFICATION OF REPORT

Unclassified
18. SECURITY CLASSIFICATION OF THIS PAGE

Unclassified
19. SECURITY CLASSIFICATION OF ABSTRACT

Unclassified
15. NUMBER OF PAGES

25

16. PRICE CODE

20. LIMITATION OF ABSTRACT

UL 



\title{
Scheduling Peacetime Rotation of Pakistan Army Units
}

\author{
Robert F. Dell \\ and \\ Richard E. Rosenthal \\ Operations Research Department \\ Naral Postgraduate School \\ Monterey. CA 93943-5000 \\ Lieutenant Colonel Shafoat Baig \\ 115 Medium Reginent Artillery \\ Pakistan Army \\ Kharian Cantt. Palistan
}

November 1993 



\title{
Scheduling Peacetime Rotation of Pakistan Army Units
}

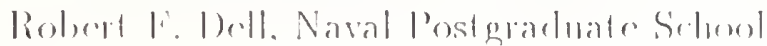

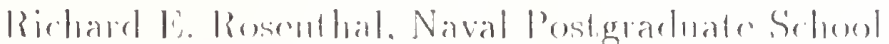

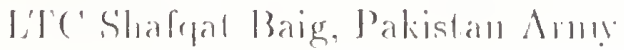

\begin{abstract}

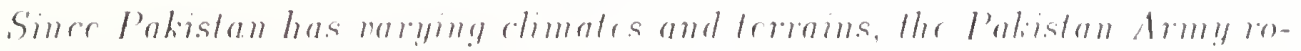
tates its units between penectime locations so that mo umit emdners inequituble

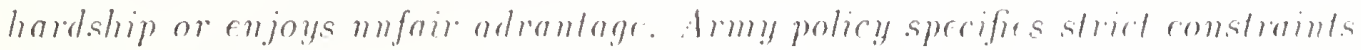
on muil rolations. sush as the lemglh of a mil's stay in an!y location. The number of units moving al an!y time. and the alloweble replarements for an!y

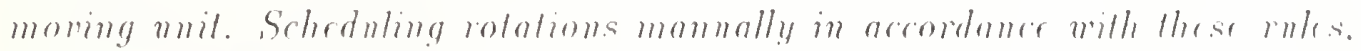

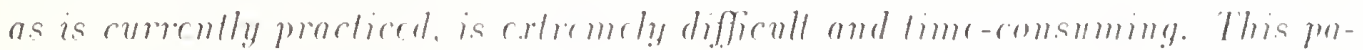
per prescuts an integre prougramming model that funds frosible. minimum-enst schedules for the Polizston drmy's desired plamming horizons. The model also cusemers that the mults are positioned at the end of the plamming horizon so lhal frasible sehedules rerist for fulmer plameres. The model is implemented

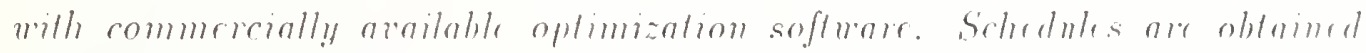

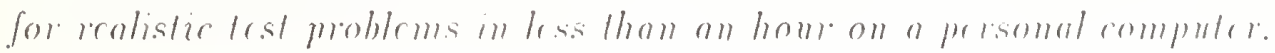

The Pakistan Army peacelime rotation problem, as describert in the ah, stract. was chosen by c'olonel Jaig as a research lopic for a masters lhesis.

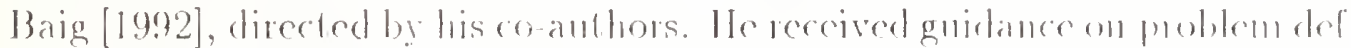
inition from Brigadier (iemoral llaroon Bashir Khan, who was lhen serving as the Amy Atlache at the Jakistan Embassy in Washingtom. The mockel presented in this paper captures all aspects of the peacetime mation problem as tescriberl by lite gemeral.

The peacetime rotation problem is a unigue scheduling/timedabling problem. It shares the diversity and large number of constraints typically 
found in the construction of sport schedules. (L.g., see Audme and Comomiras [1989] for the 1992 Smmore Olympic Cames, Sluell flosin] for the National Basketball Association, ('ain [1975] and Shell [1985] for Major Lagure Baselall, and Ferland and Flement [1991] for the National Hockey League). However, the peacetime rotation problem has relatively few erents compared to the hundreds or thousands of games that make mp a typical sports schertule. An exact procedure is therefore mudertaken in this paper instearl of the lieuristic procedures used successfully for large scale timetabling pred. Iems (arter [1986]. There following sections present: I) policics definimg the problem, 2) the iuteger programming formulation, 3) model sefincments for increased tractability, 4) computational experience, and 5) comclusions.

\section{Pakistan Army Peacetime Rotation Policies}

The Pakistan Army classifies military locations into Peare duas (PAs). SemiIlard Areas (SIIAs) anrl Iard Nreas (HAs). This classification accommts for l'akistan's diverse terrain, ranging from desert, to folty momulains. and temperatures, ranging from below lieczing to above 10 degrees ('dsius. The geographic classifications also aceomut for available facilities at the lorations and the proximity to major metropolitan areas. To custure that persement

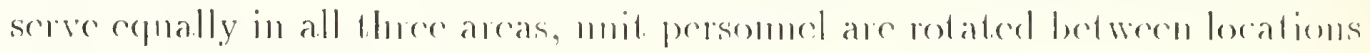
during peacetime on a regular basis.

Military units in the Pakistan Army are classifued in Huere ways: accomeling

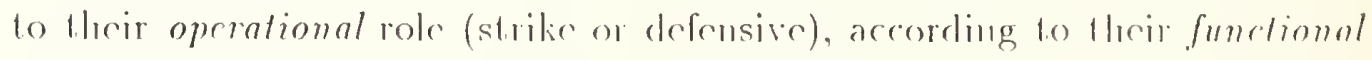
role (Armor, Artillery, Fuginoers, Infantry, Signals, Supply, ete), aurl ac:coreling to whether their equipment is supplied by Wastern or Westem bloc

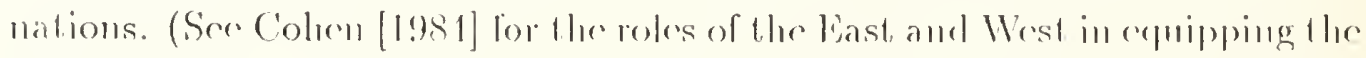
Pakistan Army.) Separating the mits into distinct categories based on tlese three attributes simplifies subserpment mathematical analysis and is useful for chociclating rotation policy. 
The Gemeral Headquarters of the l'akistan Amy las established motation policies, whose salient features are as follows.

1. A unit can move only if eplaced by a mut of the same catrgery, i.e. having the same operational and functional roles, and operating the same type of equipment. This results in a matural division of the overall problem into separate rotation problems for cach categery. "lhe largest category, currently, has $\$ T$ mits.

2. If a mit at location 1 muxes to location B3, then a mit of the same category at location 13 must move to location $A$ in the same year. 'This policy, refored to as mulual replasement, simplifies transfor of operational and arluinistative eresponsibilities at both lowations.

3. Equipment does not more, only persomel do.

4. No more than one mit can mose from the same brigarle in the same year. A brigate is composed of three mits of the same categoule.

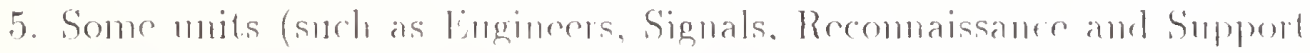
Battalions) do not belong to a brigarde. They fall moler direct contmel of a ldivisiom. 'There ran be mo more than one of these mits moving from the same location in the same year.

6. Each mit s temure requinement varies by location classification as follows:

- Peacen Area (PA) D-7 years.

- Semi-Hard Area (Silla) 2-4 years,

- llard Area (HA) 1-3 years.

7. An indiviclual moit most rotate acrording to the cyele of locations: $\mathrm{PA} \rightarrow \mathrm{SHA} \rightarrow \mathrm{PA} \rightarrow \mathrm{II} \rightarrow \mathrm{PA}$. as shown in Figure $\mathrm{I}$. 


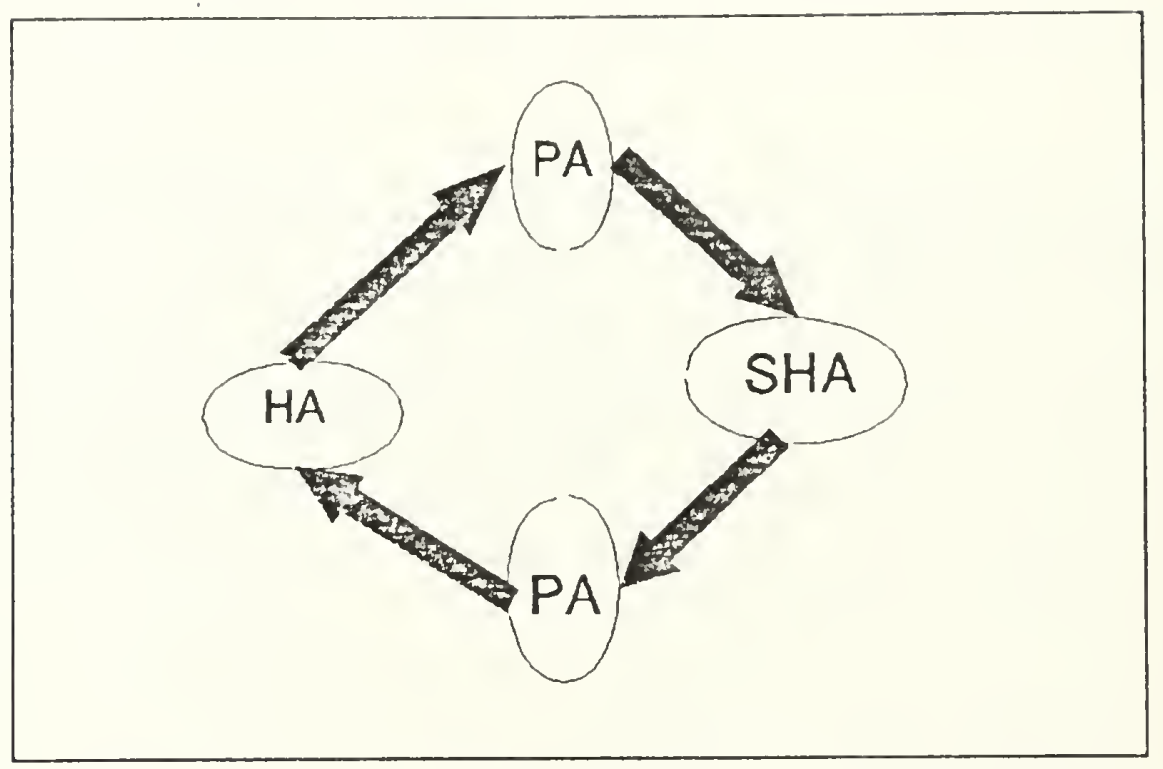

Figure 1: Each unit must rotate through Peace Areas. Sermi-Hard Areas and Hard dreas in the indicated order. Alternate Peare trens in the cycle must be different. The length of stay in each location must foll within a preseribed range.

8. There is no restriction placed on which SHA or H.A locations a unit visits on its cycle. However, a unit must not return to its previous $\mathrm{PA}$ location.

Currently, peacetime rotation schedules are developed manually by planners at the General Hearlquarters of the Pakistan Army. A five-year schechule is developed on a yearly basis. Due to the large problem size and complex policy structure, the current mothod suffers from the following drawbacks:

- The units may be positioned at the end of the planning horizon in a way that preclurles future scherdules from satisfying the policy constraints.

- The schedule requires hundreds of man-hours to develop.

- It is difficult to evaluate proposed policy changes.

- The schedule may not be developed impartially. 
- The schedule may incme exeess cost by transferring mits more often or over greater distauces than necessary.

These limbitations motivaterl the elevelopment of an integer programming modet to assist with rotation selectuling.

\section{Peacetime Rotation Model}

One integer programming moekel for the Pakistan Army"s peatedime rotation problem minimizes the total cost associated with all scheduled moves, white ensuring that all policy constraints are satisfiet. The molet is raticl for

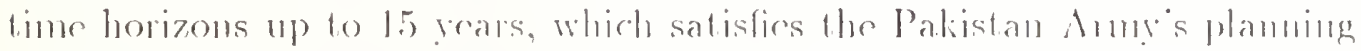
requirement for five-year wation sedierlules.

- Indices:

$i, i^{\prime} \quad$ minits.

I, l' locations,

$t, t^{\prime} \quad$ years.

- (iiven Dala:

mitli the initial location for mit?

mime minimmm stay altowerlat focationl.

marl maximm stay allewerlat locationl,

mcost. all movencme cost for mit i from / to l',

stongl number of years milt i has been at location I at the start of the first lime period,

$P$ set of prace ancalowitions.

$\mathcal{H}$ set of hard arcat locations. 
$\mathcal{S}$ set of semi-harel arca locations.

- Derived Sets: The following sots are used to conforer rotation policies. Their derivation is discussed in section 3.

Ull't set of all units elighthe to move from location l to l' in year $l$.

Filt set of all possible locations from which mit i conlel hase moverd if it arrives at locationl in yearl,

Tilt set of all possible torations fo which moit i can mose if sitmated al location $/$ in yeal 1 .

- Decision Variables:

$x_{\text {allt }} 1$ if unit i moves from lecation $/$ to location $l^{\prime}$ in geat $t$, and 0 otherwise.

- Formulation:

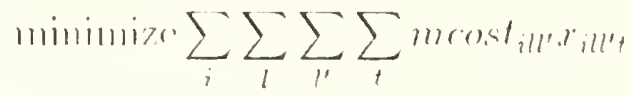

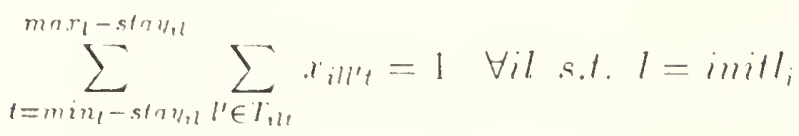

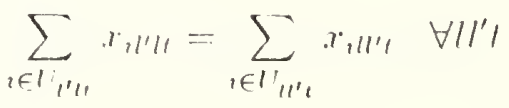

$$
\begin{aligned}
& \sum_{l^{\prime}} \sum_{i \in I^{\prime} l^{\prime} t} r_{i l l} \leq 1 \quad \forall \|
\end{aligned}
$$

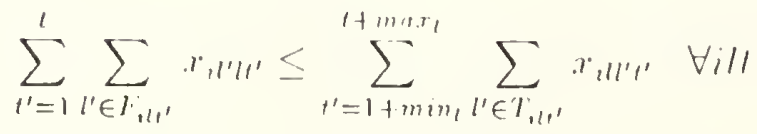

$$
\begin{aligned}
& \sum_{l^{\prime} \in T_{i l l}} r_{i l l^{\prime}} \leq \sum_{l^{\prime}=t-m a s_{l}}^{t-m+l^{\prime} \in I_{i l t^{\prime}}} x_{l l^{\prime} l^{\prime}} \quad \forall i l l
\end{aligned}
$$




$$
\begin{aligned}
& \sum_{l \in F} \sum_{l^{\prime} \in H^{\prime}} \sum_{i} r^{\prime} \|^{\prime}+\leq 1 \quad \forall i \\
& \sum_{l \in \Gamma} \sum_{l^{\prime} \in S} \sum_{i} \cdot r^{\prime} m^{\prime} t \leq 1 \quad \forall i \\
& \sum_{l \in \|^{\prime}} \sum_{l^{\prime} \in F} \sum_{t} r_{i} \|^{\prime} t \leq 1 \quad \forall i \\
& \sum_{l \in \epsilon^{S}} \sum_{l^{\prime} \in \Gamma} \sum_{i} r^{\prime} \|^{\prime} l \leq 1 \quad \forall i \\
& \sum_{l^{\prime} \in \mathcal{H}} \sum_{i} r_{i} l^{\prime}+\sum_{l^{\prime} \in S^{S}} \sum_{i} x_{n} \|^{\prime} \leq 1 \quad \forall i, l \in \Gamma
\end{aligned}
$$

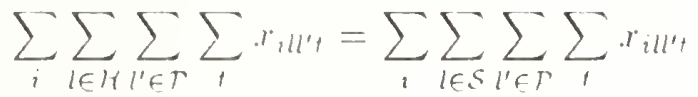

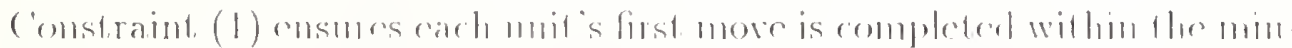

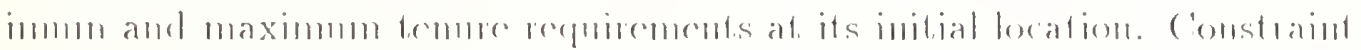
(2) cufores the mutual replacement pelicy. ('onstraint (3) allows no more than our mot to move from the same foration in the same year. If two

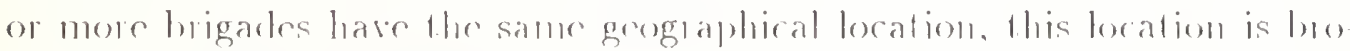

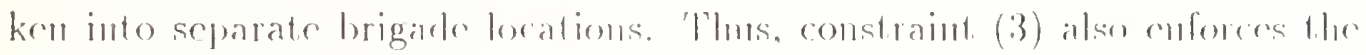

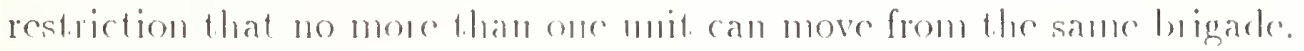

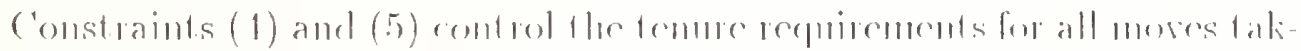
ing plare after the first mose. ('omstraint (1) restriets the mumber of times

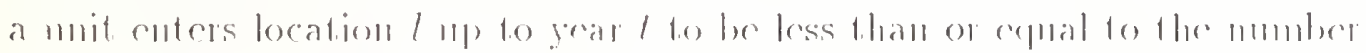

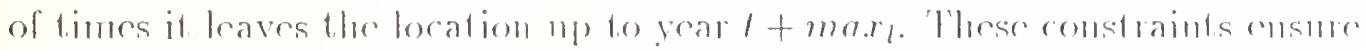
that a mit leaves a location in year lonly if it artived al that beation in an approprate earlier year. (They can alternatively be formulated with monert-

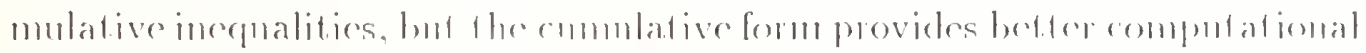
performance.) Comstraint (5) ereprires a unit leaving location $/$ in yeal 1 to have arrived theme 1 - mext to 1 - mim years carlicr. ('omstraints (1) and 
(5) camot prevent a mit from moving away from the same location more than once in the last few years. ('onstraints (6) - (9) climinate this poldem by allowing cach mit at most one mow between diflerent aleas dumg the plamming horizon (a valid restriction for planning horizons of 15 years or less).

Constraint (10) prevents a mit, from moving to the same PA more than once. If the plaming horizon is less than seven years, this comstraint is minecessary.

Constraint (11) states the total mumber of moves from IIAs to PAs shomld be equal to the total number of moves from SIIAs to PAs. This constraint helps position units appropriately at the end of the plaming horizon, as discusend further in section ?3.

\section{Model Refinement}

Even though we can treat the Pakistan Army's rotation scherhuling problem with separate models for cacl operational/functional area, He iurlependent models can still be quite large. The largest operational/functional area lase 87 mits spread over 30 locations. Straightforward application of the pre-

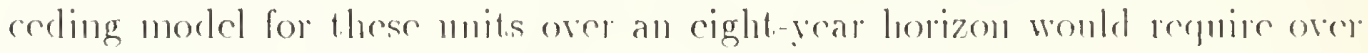
600,000 binary variables. Fortmuately, characteristics of the policies cau be exploited to identify many impossible mit movements and climinate the cor-

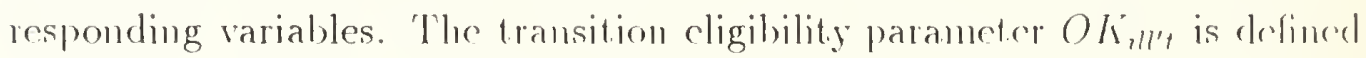
for this purpose. It has value 1 if and only if unit $i$ is eligible to mowe from location $l$ to $l^{\prime}$ in year l. The ielea is to make this parameter zoco as often as

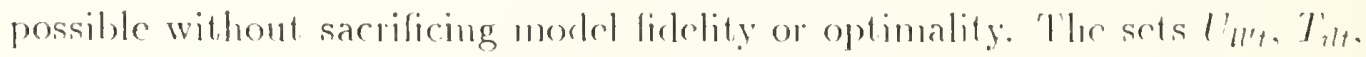

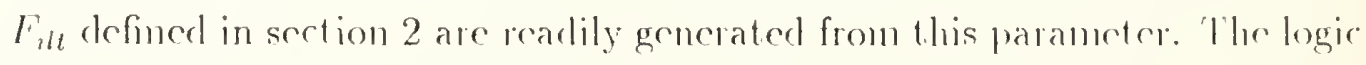
for deriving $O K_{i l l}^{\prime}$ is as follows.

1. Rotation policies and temure linuts sererely enstrict the set of allowable moves. For example, a muit that has moved from a $\mathrm{II}$ and has been at a PA for thece years can not possibly move for two more years and 
then only to a SHA. Subserpuent moves are similaty restricterl. Iluese

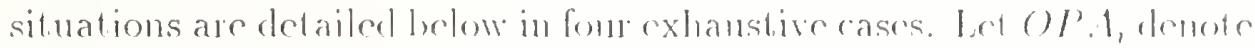

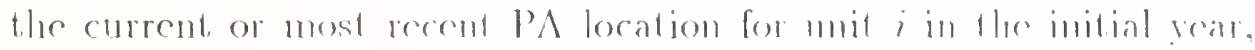

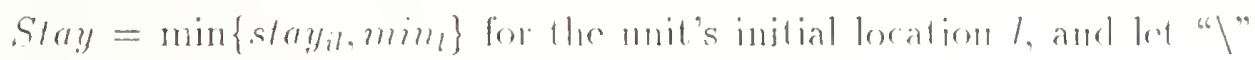
demoter set exclusion.

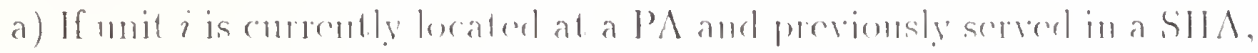

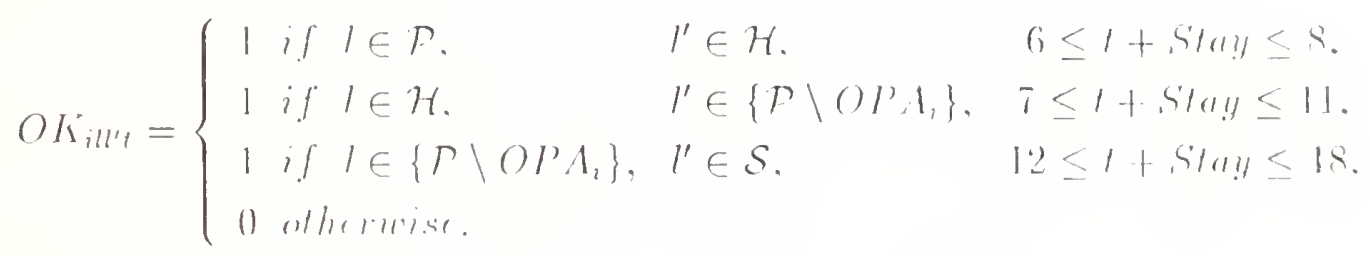

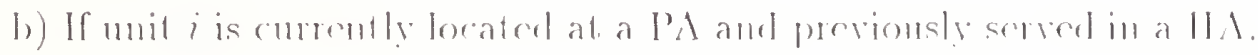

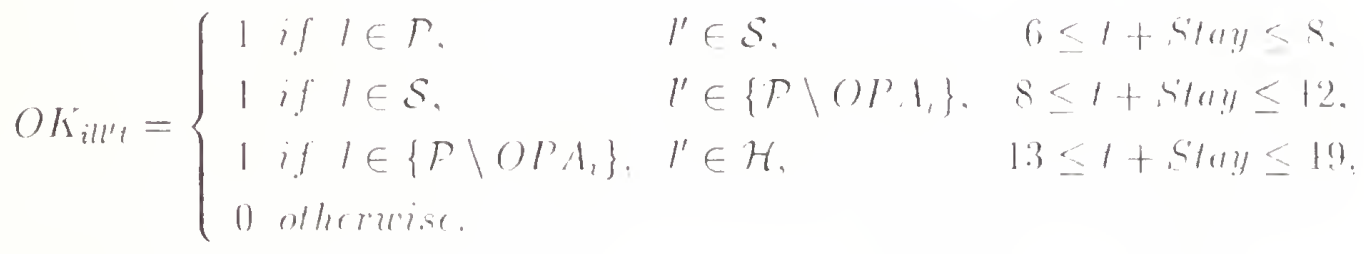

c) If unit $i$ is compoully locaterl al a Sild.

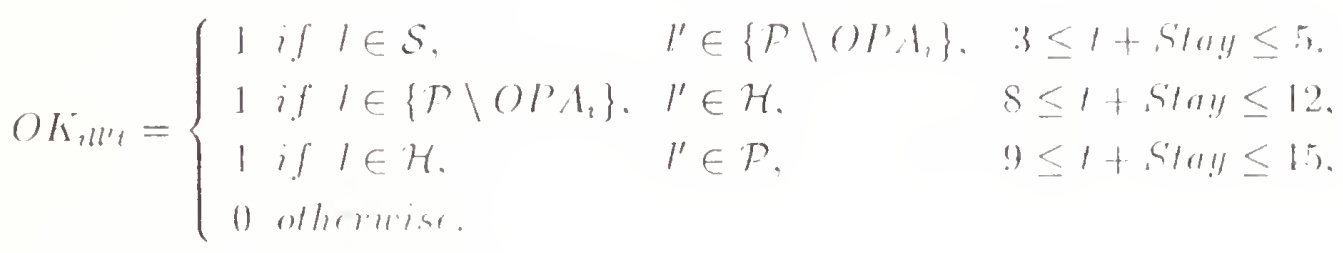


d) If miti is currently located at a. $11 \wedge$.

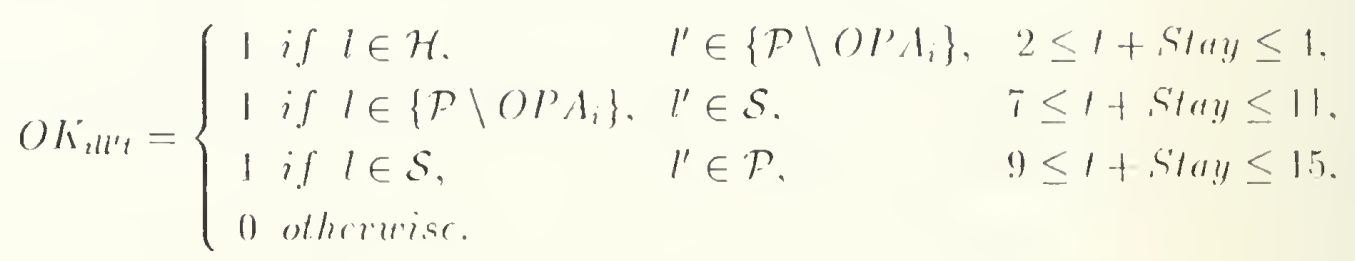

For a detailed example, smppose mit $i$ is curmenty located at a $\mathrm{l} / \mathrm{A}$ and its old location is a IIA (case b). This mil can move to a SHA after completing 5 to 7 years of stay at the PA, so it is cligilde to more only when $1+$ Shay is 6,7 or 8 years. 'The mit's next mowe to any l'A

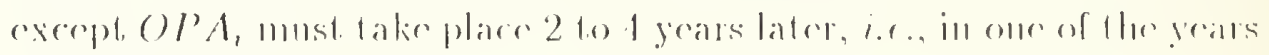
8 through 12 .

2. The mutual rotation policy also helps climinate many variables. ('onsider a unit at location / hat is cligible to move to $l$ ' in year $/$ after executing step 1. That move can be scherbled only if amother unit is eligible to move from location l' to location / in the same year. 'Therefore. any $O K$ ill't that was 1 after step 1 is changed to 0 muless:

$$
\sum_{i^{\prime} \neq i} O K_{i^{\prime} l^{\prime} l l} \geq 1
$$

3. We can extemel the irlea of step 2 to smbsequent moves. lior mitit $i$ to be eligible for a move to loration $l^{\prime}$ in year t, here must be another

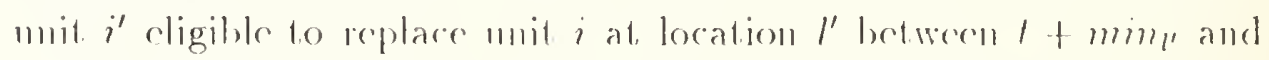

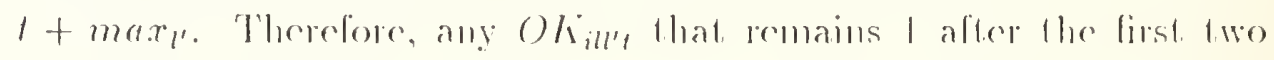
sicps is changed 1.0 0 muless:

$$
\sum_{i^{\prime} \neq i} \sum_{l} \sum_{t^{\prime}=1+\min l^{\prime}}^{1+m a x^{\prime}} O \kappa_{i^{\prime} l^{\prime} t^{\prime}} \geq 1
$$




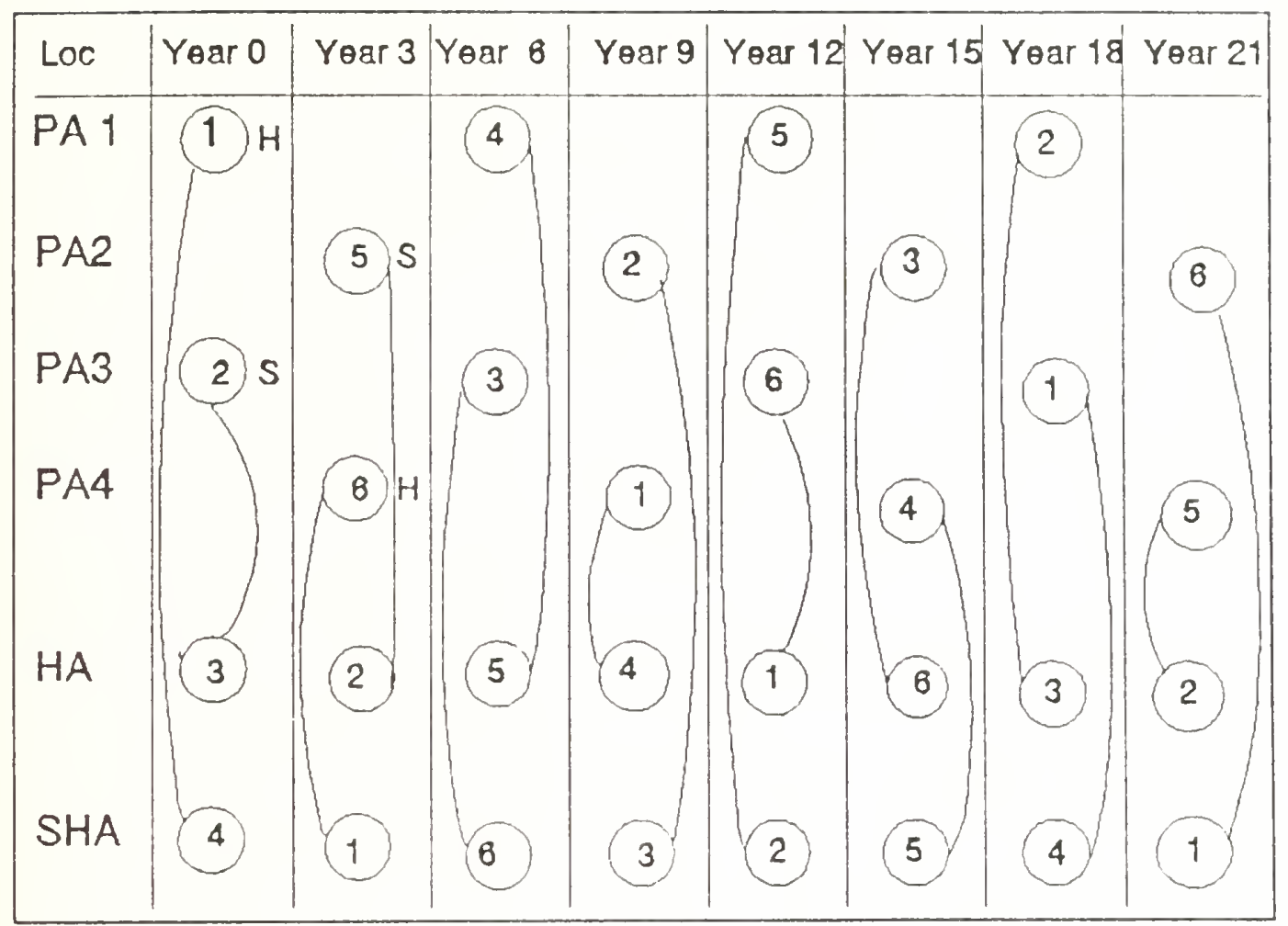

Figure 2: A feasible six-unit rotation pattern that can be extendrd indefinitcly. Vodes in the figure represent units undergoing moves in the indicated yrar. Edges represent mutual replarement.

\subsection{Conditions for Future Feasibility}

The Pakistan Army needs to ensure that units are positioned at the ent of the planning horizon so that feasible scherlules exist. for futnre planners. Sufficient conditions are developed for this purpose. These conditions are explained with the help of Figure'?

Figure 2 shows an indefinitely repeatable rotation schedule that saticfies all restrictions of the rotation poliry outlined in section 1 . This figure contains 4 PAs, $1 \mathrm{HA}$, and 1 SHA locations where each location has one unit. The circles contain unit identifiers and the arcs between the circles indirat.e units exchanging locations. For the units initially located at P.Is (1, 2. 5. and 6), their last area is shown with $\mathrm{H}$ (for HA) or $\mathrm{S}$ (for SIIA). 
I1 is possible to add mits in multiples of 6 (4 PA mits, I HA mit, I SHA

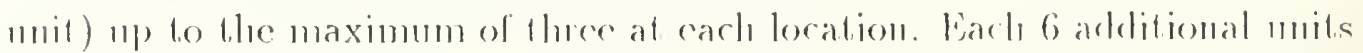
(1 at each existing location) could be feasibly adeled to the above schechule by allowing moves ius similar 3 year increments starting at year I for the first 6 milis and at, year 2 for the second o. New locations with mits following the same pattern conld also be arleled.

The positioning of muits in Figure 2 obeys the following omelitions at all limes.

Condition 1 The total number of muts in PAs is twice the mumber of mits

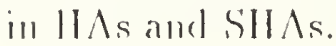

Condition 2 The number of muits in $H \Lambda$ s and SII $\lambda$ s is repual.

Condition 3 Half the mits in l'As previonsly sepved in Sill $\mathrm{As}$ and half previously served in HAs.

The three conditions above are not necessary to guaranter the existence of a feasible solulion in the future. However, as proven in the appenclix. if the conditions are satisfied for the six years preceling the current horizon and are enfored throughout the horizon. then futhe feasibility is guaranteret. Unfortunatedy, some operational/functional areas have uot always conformed to the conditions. Therefore, the test problems of section l are solved with constraint (11) insteat of the mere restrictive form of the constraint

$$
\sum_{i} \sum_{l \in \mathcal{H}} \sum_{l^{\prime} \in \mathcal{F}} x_{i} \|^{\prime} t=\sum_{i} \sum_{l \in \mathcal{S}} \sum_{l^{\prime} \in T} r_{i l l^{\prime} t} \quad \forall l
$$

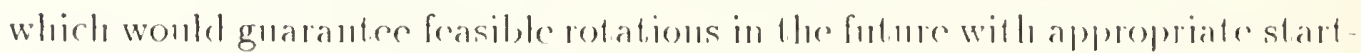
ing conditions. Though not guarantecel, constraint (11) empirically yickled rotalion selochules with ending comblitions that allowed foldure leasible rotations. 


\section{Computational Experience}

The Pakistan Army peacedime rotation model is implemented in the (ieneral

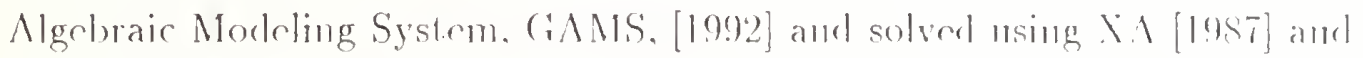
OSi. [1991]. All computational results are ohtaimed using a 4s6i/333 persomal romputer with 16 megabytes of RAM. The goal of omr worli was to dereelop

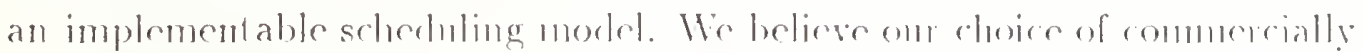
available software and a persomal computer represents the lese thane of implementation for the following reasons:

1. The Pakistan Amere an implement the model for a reasomable cost.

2. The software is stable, werl decmomented, and the user can benefit from fulure software imporements.

3. Software maintenancerest is low.

1. The software is portable to now phatforms and operating stestems.

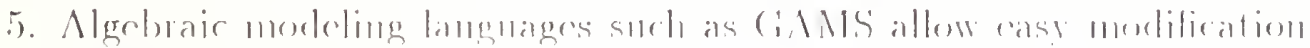
and arklition of constiatins.

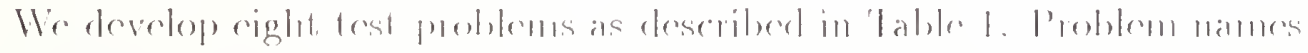

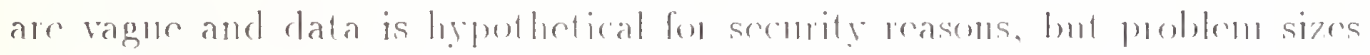

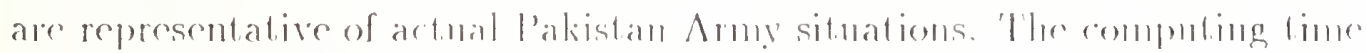

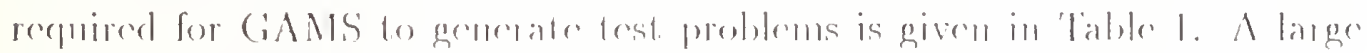
portion of the GAMS time was taken deriving the parameter ()killt.

All the test problems saltisfy ('ondilion 3 of Sertien 3 for the intial lime

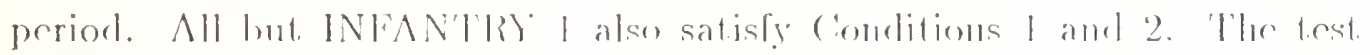
problems are all frasible. Lixperimentation with other statting comblitions often resulted in infeasibility:

The test problems of talde I were solved for integer solutions with a $10 \%$ optimality toleranee (i.r., temination oecuss when the lirst solution guaranteed within 10\% of optimal is obtained), using both the XA and (OSL 


\begin{tabular}{|c|c|c|}
\hline I'roblem Iyرer & l'olifoll Size & $\begin{array}{l}\text { ( A M MS (inclialion } \\
\text { Time (seconds) }\end{array}$ \\
\hline \multicolumn{3}{|l|}{ INFANTRI' 1} \\
\hline (i youls & 2,56 in $^{2}$ comstamints & 530 \\
\hline 87 units & 12,211 linary variables & \\
\hline 30 locations & 71,571 110117010\% & \\
\hline \multicolumn{3}{|l|}{ INFANTRY 2} \\
\hline 6 years & 1,599 constraints & 236 \\
\hline 72 mnits & 5,716 hinary variables & \\
\hline 24 locations & 35,037 nonzeros & \\
\hline \multicolumn{3}{|l|}{ ARTILLERY } \\
\hline 6 ycars & $1,0 S 8$ constraints & 151 \\
\hline 54 units & 3,140 hinary variables & \\
\hline 21 locations & $18,5.30$ molzoros & \\
\hline 7 years & $1,5(5.3$ constraints & 200 \\
\hline 54 units & 5.26 .3 hinary variables & \\
\hline 21 locations & 31,967 molnacos & \\
\hline Sycars & 2,135 comstraints & 258 \\
\hline 54 units & 7,828 limary variables & \\
\hline 21 locations & 49,393 nomzeros & \\
\hline \multicolumn{3}{|l|}{ ENGINEERS } \\
\hline 6 years & 913 comstraints & 89 \\
\hline 36 units & 2,193 hinary variables & \\
\hline 19 locations & 14,829 понж) & \\
\hline 7 years & 1,253 constraints & 116 \\
\hline 36 mils & 3,121 binary variables & \\
\hline 19 locations & 23,379 1101170\%os & \\
\hline S ycars & 1,681 constiaints & 117 \\
\hline 36 minits & 4,949 binary variables & \\
\hline 19 locations & $35,130 \quad 110117$ cros & \\
\hline
\end{tabular}

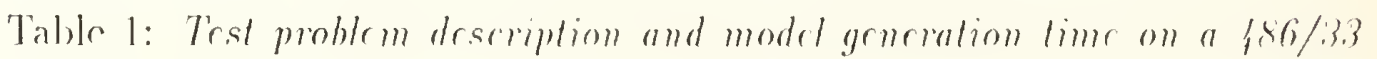
personal somputer. 


\begin{tabular}{|c|c|c|}
\hline $\begin{array}{l}\text { Problem Type } \\
\text { Horizon (Year) }\end{array}$ & $\begin{array}{l}\text { Solution Time } \\
\text { seconrls (solver) }\end{array}$ & Iterations \\
\hline$\frac{1 N I \triangle N T R Y 1}{t=6}$ & $\begin{array}{l}3,575(\mathrm{X} \Lambda) \\
2,335(0 \mathrm{~s} 1 .)\end{array}$ & $\begin{array}{l}37,919(X \Lambda) \\
7,062(0) 11)\end{array}$ \\
\hline$\frac{\text { INEANTRY } 2}{t=6}$ & $\begin{array}{r}1,568(X \Lambda) \\
152(0 S 1,)\end{array}$ & $\begin{array}{l}21,647(X \wedge) \\
3,178(0 \mathrm{OS1})\end{array}$ \\
\hline$\frac{\text { ARTILLLRS }}{t=6}$ & $\begin{array}{c}9.5(X A) \\
173(0 \mathrm{SH})\end{array}$ & $\begin{array}{l}2,519(\mathrm{Y} \backslash) \\
2,196(0.51)\end{array}$ \\
\hline $1=7$ & $\begin{array}{l}679(X \lambda) \\
211\left(\left(0 \mathrm{SI}_{2}\right)\right.\end{array}$ & $\begin{array}{l}14,969(\mathrm{X \Lambda}) \\
1.998(0 \mathrm{si1})\end{array}$ \\
\hline $1=8$ & $\begin{array}{l}x(X N) \\
15(0 S 1)\end{array}$ & $\begin{array}{c}\propto(X \Lambda) \\
3,612(0 S 1) \\
\end{array}$ \\
\hline$\frac{\text { ENCINELRS }}{t=6}$ & $\begin{array}{l}165(\mathrm{X} \mathrm{A}) \\
105(0 \mathrm{S1})\end{array}$ & $\begin{array}{l}1,735(\mathrm{X} A) \\
1,391(\mathrm{OSH})\end{array}$ \\
\hline$t=7$ & $\begin{array}{l}2,85.5(X \Lambda) \\
311\left(0 \mathrm{SI}_{2}\right)\end{array}$ & $\begin{array}{l}51,769(X) \\
3,391 \text { (OSII })\end{array}$ \\
\hline$t=8$ & $\begin{array}{l}8,950(X \wedge) \\
1,(627(0 S 14)\end{array}$ & $\begin{array}{l}105,918(\mathrm{XA}) \\
11,212(0 \mathrm{SI})\end{array}$ \\
\hline
\end{tabular}

Table 2: Tres Problem Solution Times 
solvers. All tuming parancters were lelt at their default values. Table 2 demonstrates these results and highlights OSt;s superior performance in all but one case. XA was mable to solve the linear programming relaxation of the S-year Artillery problem apparenty due to cycling.

For completeness of the computational testing. all problems were also solved to optimality (i.e., with the optimality tolerance set to zero). The integrality gap (difference between the optimal linear and integer prograntming objective function vahues) is zero in five of the eight preblems tested and less than $3 \%$ in the other cases. For the five examples with no integrality

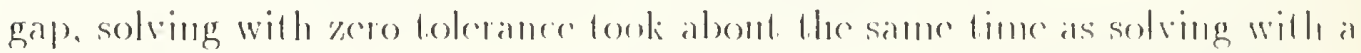
$10 \%$ tolerance; but the ofluer theres examples took signilieantly longer. Simer the integrality gap was so small, the adeled computational time for the zeco

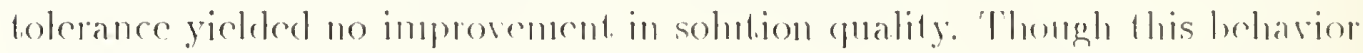
cannot be guaranteet. We recommenel using the $10 \%$ optimality tolemanee (the (iAMS default) for future instances of this problem.

\section{Conclusion}

Computational experience will the model denomstrates that optimal mit rotations can be developed for $6-8$ year horizons on a personal computer in less than an homr, wsing the (i A MS morleling langnage aud the ()Si, solver.

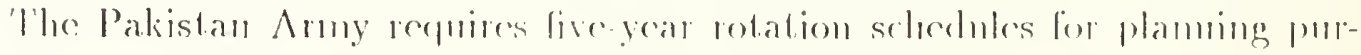
poses, so the 6-8 year selwedules we hawe obtained are more than arteplate in scope. 'The computation times are considered aceptable and represent a

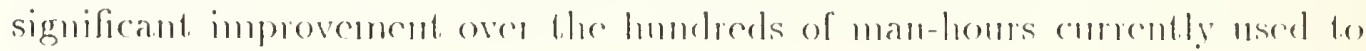
solve the problem.

'This work offers some general lessoms for practical application of optimization morleling.

- Use general purpose software when possible. Compared to sperial. purpose algorithms, the costs of development and long-term mainte- 


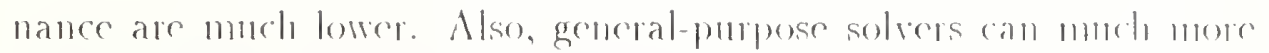
rearlily adapt to dranges in hire problem.

- Using an algebraic morleling language to grmerate the model facilifates rapid assessmem of compmtatiomal tractability and allows sereal solvers to be tested competitively with minimal offolt. In om expe. rience, integer progemmong applications are foo valierl for any onc solver to always oufperfomm he others. (F.g., thomgh XX lost to osit,

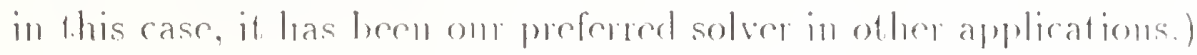

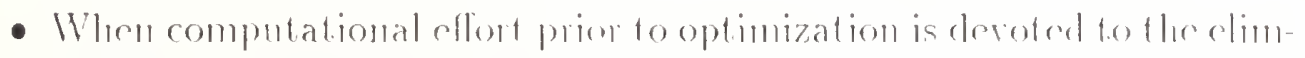
ination of muneressaly valiables, this refinement can oftem malse latgrscale instances of real-merlel problems tractalsle.

- Mathematical amalysis loarling fo arlitional comstraints beyomel Hose specified hy the origimal publem statement such as the comstraints on

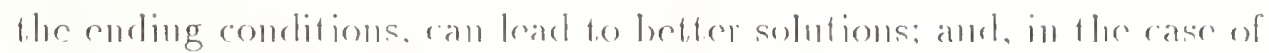
integer programming, carefully chosen extra comstraints often make the model casior to solve.

\section{Acknowledgements}

The anthors would like to thank Brigadier Gemeral Iaroun Bashir Khan of the Pakistan Amy for guidance on defining the rotation polieies and l'o-

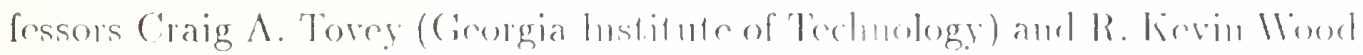
(Naval Postgraduate School) frof fmithul discussions of this poblem. This pa-

per lias also benefited from critical readings by the referees and Puofessons

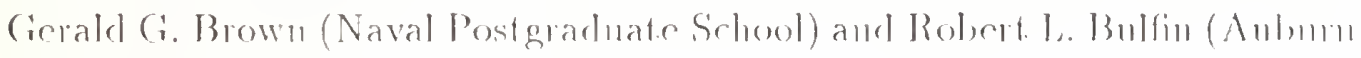
University).

The work of the first anthor was supported, in pat, ly the Naval Post. gracluate School tesearch imitiation program; this suppont is gratefully ace knowledgerl. 


\section{References}

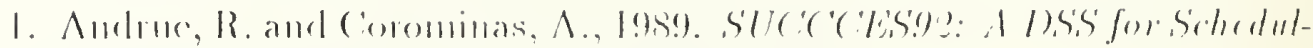
ing the Olympir Cinmes. Interfaress 19, 1-12.

2. Baig, S., 1992. Sicherduting the Pearetime Rotation of Politastan Army Units, Masters Thesis, Oprotions Rescarch Departureut, Naval Post graduale School, Mouterey, $(: \Lambda$.

3. Brooke, A., Kondrick, 1), and Mecraus, A., 1992. (BAMS: A Usrr's

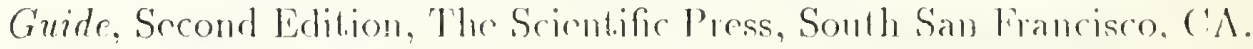

1. Cain, W.O., 1977. Thr Compuler-Assisted Mruristir Apmonerh IJsed to Schrdule the Majom Lragur Baserball ('Mubs. Optimal Strategies in Spurts. Studies in Management Science and Srstems 5, 32-41.

5. Carter, M.W., 1986. A Survey of Proctionl Applications of liramination Timetabling Agorithms. Operations Rescarch 31, 1933-202.

6. Cohen, S.P., The P'olistan Army, Wniversity of Califormia P'ress. Borkeloy, (`A $198,1$.

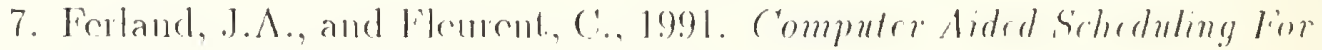
A Sport leagur. INVOR 29, 1 1-25.

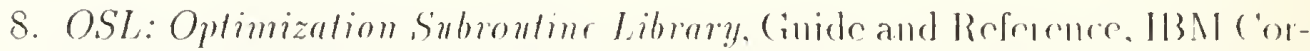
poration, Kingstom. N.Y. 19!9!.

9. Shell, E.R., 1985. Moking Up, Sponts Schedules is ()ur (iome Nobody

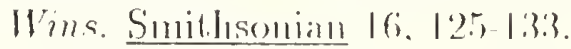

10. XA: Professional Linear Programming System, Sunset Software Tredtnology. San Marimo, ('A. 1997. 


\section{Appendix}

Theorem If Condilions 1, 2 and 3 of Section 3 are saticlied for six years. they are sufficient to guarantere a future foasible motation selierlute. PROOF:

Condition 3 stipmlates that half the mits in P'As must have previously served in IIAs and half in Sil As. This status is maintaned on a yerly lasis

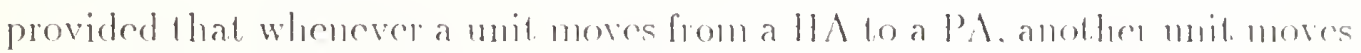
from a SHA to a PA. The mits at IIAs and SHIAs can therefore be separated into pairings which salisfy one of the following there cases.

- CASE I. A mil has been at a HA for l year and another mil has been at a Sill for 1 year.

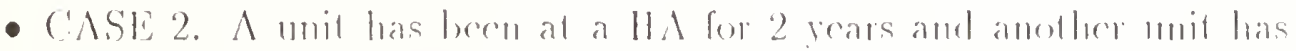
been al a SHA for ?yers.

- CASE 3. A mil has beem at a HA for 3 years and another mit has been at SHIT fol i yeats.

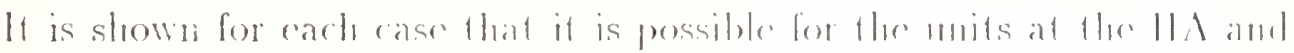
SHA to feasibly rotate in the same real with a mit cumenty at a J'A location. Auy six units satisfying ('onditions 1, 2 and 3 for thr last fo years and frasibly rotating can be used. Willout lese of generality the six mits are mumbered

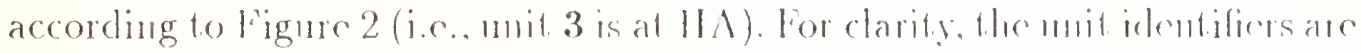
bold faced. Also, as in Figme 2, year 0 is comsidened the first reat aratable to rhange a mil's location.

( NASTI I

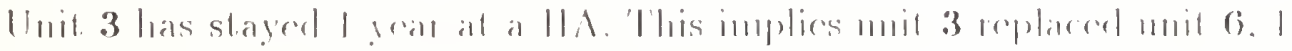
year ago and mith 6 replared muit 1 either 2,3 or l yours ago.

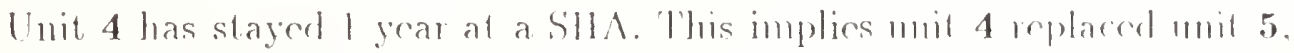
1 year ago and mit, 5 replaced muit 2 either 3,4 or 5 years age. 


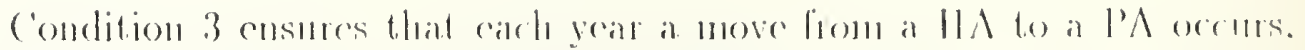
a move from a SHA to a $\mathrm{P} \Lambda$ also occurs. Therefore, we need only consider unit 6 (5) replacing mit 1 (2) rither 3 or 4 years ago.

These conditions provide the following rotation eligibilities:

Unit 4 is eligible to move in years 1,2 or 3 and Unit 1 is eligible to replace unit 4 in years 2,3 or 4 if unit 1 was replaced 3 years ago, or in years 1,2 or 3 if unit, 1 was replacerl 1 years ago.

Unit 3 is eligible to move in years 0,1 or 2 and Unit 2 is eligible to replace unit 3 in years 2,3 or 4 if moit 2 was replaced 3 years ago, or in years 1,2 or 3 if unit. 2 was replaced tyears ago.

Therefore, it is feasible for both wnit 3 and muit 4 to rotate in year 2. CASE 2

Unit 3 has stayed 2 years at a II 1 . This implies muit 3 replaced mil 6, 2 years ago and mith 6 replaced muit 1 either 3,4 or 5 years ago.

Unit 4 has stayed 2 years at a Sll $\Lambda$. This implies unit 4 replaced mil 5. 2 years ago and unit 5 replaced unit 2 cither 4,5 or 6 years ago.

Condition 3 ensures that eaclu year a move from a $I 1 \Lambda$ to a $\mathrm{l} \Lambda$ occurs, a move from a SHA to a l'A also occurs. 'Therefore, we neerl only consider unit 6 (5) replacing wnit 1 (2) cither 4 or 5 years ago.

These conditions provide the following rotation eligibilities:

Unit 4 is eligible to move in years 0, 1 or 2 and Unit 1 is eligible to replace unit 4 in years 1, 2 or 3 if unit 1 was replaced 4 years ago, or in years 0,1 or 2 if minit 1 was replacerl 5 yoars ango.

Unit 3 is eligible to move in years $-1,0$ or 1 and Huit 2 is cligible to replace unit 3 in years 1, 2 or 3 if muit 2 was replaced 4 years ago, or in years 0, 1 or 2 if unit 2 was replaced 5 years ago.

'Therefore, it, is feasible for both mit 3 and mit. 4 to rotate in year 1. CASE 3

Unit 3 has stayed 3 years at a 11 A. This implies muit, 3 replaced mnit 6, 3 years ago and unit 6 replaced milit 1 eitliee 4,5 or 6 years ago.

Unit 4 has stayed 3 year at a SIIA. This inplies unit 4 replaced unit 5 , 
3 years ago and unit 5 replaced mit 2 either 5,6 or 7 years ago.

Condition 3 cusures that cach year a move from a $11 \lambda$ to a $\mathrm{l} A$ orcurs.

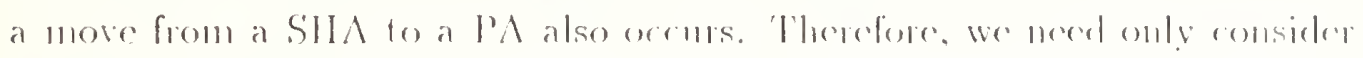
unit. 6 (5) replacing mit 1 (2) cither 5 or 6 years ago.

These conditions proviele the following rotation eligibilities:

Unit 4 is eligible to move in yeas $-1,0$ or 1 and Init 1 is cligible to replace mit 4 in years 0, 1 or 2 if muil 1 was molaced 5 years age, or in years - 1 , or 1 if unit 1 was replaced 6 years ago.

Unit 3 is eligible to more in years $-2,-1$ or 0 and Unit 2 is cligible to replace unit 3 in years 0 . I or 2 if mit 2 was replaced 5 years ago, or in years - 1 , 0 or 1 if unit 2 was replaced 6 years ago.

Therefore, it is feasible for loth unit 3 and unit 4 to lotate in year (). 


\section{INITIAL DISTRIBUTION LIST}

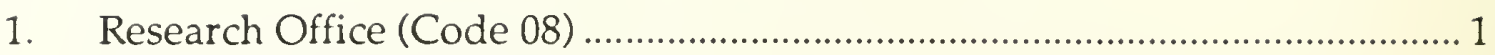

Naval Postgraduate School

Monterey, CA 93943-5000

2. Dudley Knox Library (Code 52) ................................................................. 2

Naval Postgraduate School

Monterey, CA 93943-5002

3. Defense Technical Information Center

Cameron Station

Alexandria, VA 22314

4. Department of Operations Research (Code OR)

Naval Postgraduate School

Monterey, CA 93943-5000

5. Prof. Richard E. Rosenthal (Code OR/Rl)

Naval Postgraduate School

Monterey, CA 93943-5000

6. Prof. Robert F. Dell (Code OR/De)

Naval Postgraduate School

Monterey, CA 93943-5000

7. Lieutenant Colonel Shafqat Baig 115 Medium Regiment Artillery

Pakistan Army

Kharian Cantt, Pakistan 



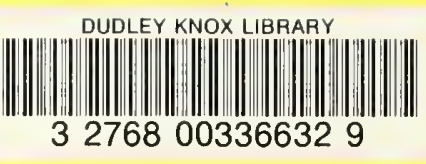

